\title{
THE OCCUPATION OF THE CRIMEAN PENINSULA BY THE RUSSIAN FEDERATION AND THE CHANGES IT CAUSED IN THE SECURITY PARADIGM IN THE BLACK SEA BASIN
}

\author{
Marcel RUSU * \\ Alexandru Ioan Cuza University of Iași, Romania, \\ e-mail: marcelrus23@yahoo.com
}

\begin{abstract}
Citation: Rusu, M. (2020). The Occupation of the Crimean Peninsula by the Russian Federation and the Changes it Caused in the Security Paradigm in the Black Sea Basin. Revista Română de Geografie Politică, 22(1), 9-19. https://doi.org/10.30892/rrgp.221102-329
\end{abstract}

\begin{abstract}
The low security level in Ukraine forms the latest and still permanent conflictual situation which results the country's territorial disputes in the international level. NATO intended to exclude Russia from the main world leader countries' range so the EU's, and in the same time the NATO's, intention to get closer to Ukraine, seemed a threat for the Russian Federation. The Russian Federation, in order to obtain their position between the major world leader counties, still exercises pressure on the Black Sea area, which activities constitute the abuse of energy and military power as well as the support of the Post-Soviet, Black-Sea region countries separatists. In conclusion the NATO as well as the Russian Federation needs to make steps towards each other, because it is true that Russia can exercise a leader role in the Black Sea region which affects the whole world's market economy and also the EU. The article contains a comprehensive description of the events of annexation of the Crimean peninsula by the Russian Federation, and the local, regional and global geopolitical changes caused by this movement..
\end{abstract}

Key words: Crimean Peninsula, international relations, Russian Federation, EU, Frozen conflicts

\section{INTRODUCTION}

The frequent major changes that have been observed in the last decade not only at regional level, but also at global level, have managed to cause a repositioning of the main political forces at the international stage level, the effects of which can be noted especially in terms of global geo-security, which is characterized in the last period by an unprecedented complexity and risk of instability.

This article examines the construction of 'geopolitical spaces' in Russian foreign policy since Vladimir Putin became President in 2000. It analyzes the way in which the three principal 'geopolitical spaces' in Russian foreign policy -

\footnotetext{
* Corresponding Author
} 
Eurasia, the Euro-Atlantic and the Asia-Pacific - are defined by the political leadership in Moscow (Clover, 1999). In a second step, this article analyzes how this traditional geopolitical imagination changed in reaction to the events in Ukraine starting in late 2013, and with the implementation of the Eurasian (Economic) Union. It is argued that the crisis in Ukraine and the subsequent deterioration of relations between Russia and the West left a decisive imprint on the way in which the geopolitical imagination of Russia's leaders evolved (Ambrosio and Vandrovec, 2013).

Based on a critical geopolitical analysis, suggesting that territory, space and geographies are being actively (re)formulated by those in power, this article analyzes how policy-makers define and articulate the importance of a particular geographical region for their foreign policy. At the center of this article is an analysis of Russian foreign policy discourse allowing us to depict the principal geopolitical regions with which Russia interacts as well as their respective importance for Moscow.

\section{CRITICAL GEOPOLITICS AND FOREIGN POLICY}

Following the many transformations that the global and the regional security environment has undergone in the recent years, ${ }^{1}$ the international community has begun to become increasingly concerned not only with global security, but also with identifying various solutions of maximum efficiency dedicated to the consolidation and maintenance of political, economic, and geostrategic stability, especially in the areas that specialists have flagged as real potential focal points for manifesting conflicts.

This is, in fact, the main reason why the most important political leaders of the world are constantly interested in identifying and implicitly implementing not only optimal, but also viable solutions, mainly dedicated to considerably reducing the various conflict situations (regardless of their nature). ${ }^{2}$ At the same time, the aim is to reduce and eliminate the potential causes that can, in a certain context, trigger various conflicts, with unintended effects.

At present, the whole world, and especially the European continent is in a particularly hectic period, characterized by a multitude of challenges determined by the changes observed in the zonal, regional and national security environments, but especially by the new reconfigurations observed by the international political scene. In this particular context, the Black Sea area has become a real target in the great processes that are in progress or only anticipated at the moment.

This is also the reason why a permanent evaluation of the regional policies carried out by the main statal and suprastatal actors is required, in parallel with the constant analysis and evaluation of the vulnerabilities, dangers, risks and even the threats that target it.

This evaluation involves analyzing a complex of indices, respectively specific indicators of zonal and regional security and stability, of which it is worth mentioning the degree of stability of the internal policy carried out by the states directly involved, the variety of problems and challenges identified on the economic level, the allocation and distribution of resources, as well as their use, access and control to the main energy resources, the stage of the reforms signaled

\footnotetext{
1 https://fas.org/sgp/crs/natsec/R43838.pdf

2 http://www.un.org/esa/socdev/rwss/docs/2001/15\%20Armed\%20Conflict.pdf
} 
at the level of the various military organizations, as well as the collaborations and agreements that are concluded at regional level and not only.

The special instability on the international scene, which has been noticed especially in recent years (manifesting not only at regional / zonal level, but especially at global level), and which has been mainly generated by the increasing number of reactions, challenges, phenomena, or processes that are quite difficult to predict, has led to an exponential development of the potential scenarios dedicated to the triggering causes, and respectively their subsequent effects.

Most of the major geopolitical events were reported especially in the proximity of the Black Sea area. This region is positioned in direct inter-dependant relation with the trend of the evolution of the international security environment. And most of these geopolitical events were determined by the complex process of advancing the Euro-Atlantic border towards the area dedicated to Central Asia, in the context of the many indecisions that were reported at the level of several institutions that are responsible for border delimitation activities on extended level, so as to observe the inclusion of all the states that set out to become an integral part of the newly delimited Euro-Atlantic space.

\section{THE FOUNDATIONS OF RUSSIAN FOREIGN POLICY}

This study is grounded in the tradition of practical geopolitics, which focuses on the political elite, and thus omits a range of other actors that equally influence Russia's geopolitical imagination. There is already a wide variety of scholarship focusing for instance on the writings of prominent academics (Tsygankov, 2003) or the examination of geopolitical perceptions of ordinary Russians and popular ideas about Russia's place in the world (O'Loughlin et al., 2006).

In the Black Sea area major changes were noted at the beginning of the ninth decade of the previous century, ${ }^{3}$ the collapse of the communist bloc generating multiple effects not only at the level of the political scene, but also at the level of the military field, and of the economic domain. As a result of the disintegration of the USSR, ${ }^{4}$ the number of the Black Sea coastal states increased (it reached six), and two of the new communist states, Georgia and Ukraine, succeeded in owning ports, sea bases, but also their own fleets.

In parallel, the numerous processes related to the transition from the socialist economy to the market economy, paired with numerous political changes, caused numerous major changes in the region, the political transformations subsequently causing many incommensurable effects 5 both at the level economics, as well as socially. Thus, while Ukraine has made numerous efforts to gain some influence in the navigable control of the region, Turkey has opted to enlarge, modernize and secure its fleet, the known fact being that it is naval forces that give the dominant role in the balance of power of the states in the Black Sea region (Vlad et al., 2010).

In addition, Ukraine has tried to diminish the control of our country at the mouths of the Danube, by building the water canal dedicated to maritime vessels on Chilia, thus trying to maximize the special advantage of the access to the area, both from an economic point of view, but also strategically and politically. This is because, due to the numerous economic interests determined by the identification

\footnotetext{
3 http://www.epc.eu/documents/uploads/pub_1363_the_democratic_transformation_of_the_balkans.pdf

${ }^{4}$ http://www.usislam.org/pdf/collapse-of-the-soviet-union.pdf

5 http://www.clingendael.nl/sites/default/files/20060800_cdsp_occ_leitenberg.pdf
} 
in Central Asia and the Caucasus of impressive natural gas and oil reserves, the Black Sea region has become a true geostrategic stake for many countries of the world (Maior and Konoplyov, 2011).

And capitalizing on the position held by the region (the transit area between Central Asia and Europe, the Middle East and the South East of the Mediterranean), as well as the immense commercial potential it represents, have made the area a real attraction for Western powers (United States, some states of the European Union, Russia). ${ }^{6}$ Both the management of the Black Sea region and its control constitute a real challenge for the states of the world, all being primarily concerned with commercial interests and subsequently with security interests. ${ }^{7}$

In the category of factors that significantly influence the interest for the Black Sea region, we note the special geographical positioning (respectively at the intersection of areas of vital importance in the geostrategic and geopolitical domain - Eastern, Central and Southern European area), access to the ocean for states such as Ukraine, Bulgaria, Romania and the trans-Caucasian states, the positioning on the route of the main power line, as well as on the transport routes of the carburants coming from the Caspian and Central-Asian areas, the numerous special natural resources, etc. 8

Under these conditions, more and more states are showing evident concerns for the redefinition of the influence and power factors in the area, that is recognized by the great state powers for their huge energy potential, as well as for the multiple economic opportunities they present. In recent years there has been a focus of attention on the Black Sea area, the most important stake being the Caspian oil, which presents interest not only for the Russian Federation, but also the United States and some states of the European Union.

Regarded by most states as a connecting bridge, the Black Sea area continues to present great interest to the great powers of the world for the special energy resources, and especially for the important trade routes it holds that facilitate trade between the European and Asian continents, as well as continental exchanges between the North and the South, including the link between the Black Sea and the Baltic Sea.

The multiple economic interests manifested in recent years in the Black Sea area following the discovery of important oil and natural gas reserves in the Caucasus and in the central area of the Asian continent have transformed it into a special geo-strategic stake for the great states of the world (Chifu, 2013). Also, as a result of taking advantage of its position in the area, namely that of continental and regional transit, the Black Sea area has come to position itself at the top of the interests of the states of the world, its management, and the possibilities of control over it representing the real challenge. of contemporary society, especially in the context of recent security and economic interests (King, 2004).

The numerous geopolitical and geostrategic changes in Eastern Europe do not seem to be resolved yet, despite the fact that these processes were started in the early 1990s, shortly after the fall of the communist power in the Eastern European area (Dughin, 2011). After the dismantling of the communist regimes and subsequently the collapse of the Soviet colossus, the U.S.S.R., the Russian Federation seems by no means ready to give up its numerous

\footnotetext{
${ }^{6} \mathrm{http}: / /$ www.epc.eu/documents/uploads/pub_1363_the_democratic_transformation_of_the_balkans.pdf

7 http://ejes.uaic.ro/articles/EJES2014_0501_VLA.pdf

8 http://www.afahc.ro/ro/revista/Nr_1_2012/Articol_Lazarescu.pdf
} 
hegemonic claims within the space dedicated to the Commonwealth of Independent States (Dunlop, 1995).

Despite the many assurances and promises made over time, not even the main Western European leaders have shown themselves willing, at least until now, to offer the full political, economic, social and military support to the states in this part of the European continent, in order to accelerate the democratization process, which is still incomplete (Buzan, 2000). These issues become all the more incomprehensible since, at least formally, some states in the aforementioned area are members of the North Atlantic Alliance, but also of the European Union.

Among all, one of the most notable is the so-called "Ukrainian spring", an unprecedented political crisis, which has led to many effects and consequences for all the great states of Europe, but also for the US, which are still manifesting up to the present day. The complex analysis of the various evolutions that have been recorded over the last years in the main areas of Ukraine (especially the eastern and western areas) reveals that a certain territorial and political type of division can be identified at state level, but also other divisions considered politically, culturally, socially and religiously (Walker, 2015). As a result of these complex divisions, the problems in the area have aggravated, starting to manifest themselves mainly after the fall of communism, the dismantling of the former U.S.S.R. colossus, as well as after the act of Ukraine's declaration ofindependence on August 24, 1991 (Ingram, 2001).

\section{THE IMPACT OF THE UKRAINE CRISIS}

Ukraine is considered by many political analysts to be the triggering factor for the failure of the reform process initiated in the former U.S.S.R., proclaiming its independence (by the Verkhovna Rada) and subsequently underpinning the launch of the C.I.S. project, that is, the Commonwealth of Independent States. After declaring its independence, the vast majority of the population believed that this would represent the idea of a national state. However, history has shown that, despite the special prospects, unforeseen situations can occur frequently, situations which over time have led to a dramatic decrease in the standard of living among the Ukrainian population, which has also lost its initial nationalistic euphoria.

Both historically and geopolitically, because of its borders, Ukraine has been perceived by specialists as a particularly fragile state, the main problem being generated by the lack of elements of national unity. Looking strictly from a geopolitical point of view, the state of instability in the Ukrainian territory can entail a potential danger of the disintegration of the state, the main threats coming from within. These threats can be generated by the following factors:

- the repercussions of the global economic crisis in 2007;

- the current political situation;

- the various differences of opinion between the main groups of the political scene;

- the numerous conflicts that occur spontaneously in the various regions of the Ukrainian territory.

As for the main areas of Ukraine, the western part of it is represented by Ukrainian nationalists, who have already expressed their intention for full independence from the Russian capital. In addition, the aim is to be oriented towards Western Europe, in parallel with the integration within the various Euro-Atlantic structures. At the opposite pole of these options there are the Russian-speakers from the eastern and southern part of Ukraine (especially 
those from the Donetsk basin and the Crimean Peninsula), who have expressed their desire to start and develop various cooperative relations with the Russian Federation. In addition, an integration of Ukraine within the various economic, political and security structures within the Community of Independent States (C.I.S.) is desired.

According to analysts, these disagreements between the population consisting exclusively of Ukrainians and the population in various regions of the state can threaten quite seriously both the independence of Ukraine and its integrity. In addition, the numerous regional tensions have over time transformed into quite insistent demands for autonomy, the most vehement of these coming from the area of Russian speakers in Crimea and in the eastern part of the Ukrainian territory.

Due to unprecedented political fragmentation, Ukraine has been artificially divided into two parts (western and eastern), each trying to identify the best solution to survive economically by various means and methods (Menon and Rumer, 2015).

Crimea has always been Ukraine's main problem, because of its special strategic position within the southern borders of the Russian Federation and of the CIS, thus the pro-Russian secessionist movement of the peninsula severely affected the territorial integrity of the Ukrainian state, in addition to the close economic, military and cultural links that exist between Crimea and the Russian Federation.

It is well known that the Crimean Peninsula represented a Russian (historical) territory, which was transferred to the Ukrainian state during 1954 through the interventions of the former ruler of that time, Nikita Khrushchev. This explains why the secession of the peninsula became a real one, generating a true conflict within the region, with effects that were reflected especially on the economic potential, which has entered a downward trend.

The crisis triggered in the Crimean Peninsula in early 2014, was signaled after the departure of President Viktor Yanukovych from power, which was caused in particular by the numerous anti-government protests in 2013-2014.

The factor that underpinned this process was represented by the rescission of the law regarding the languages that had regional status, among which were the various languages used in the Ukrainian state, languages that were eliminated from the official use.

With regard to this unprecedented crisis in the recent history of the European continent, several so-called groups could be observed, as follows:

- various Russian-speaking groups - they did not agree with the new political changes imposed by Kiev, calling for Russia's Crimean Peninsula to join;

- various groups of Ukrainians and Tatars from the Crimean Peninsula gave full support to the so-called "Euromaidan" movement.

On February 23, 2014, the Verkhovna Rada of the Ukrainian state decided to rescind the law regarding the bases of state policy in the complex field of linguistics. This law had given the Russian language the status of regional language in almost half of the Ukrainian administrative regions (13 out of 27) where members of various ethnic communities accounted for over $10 \%$ of the total population.

On exactly the same day, the Russian Federation decided to mobilize numerous rapid intervention forces at the border area with Ukraine and in Crimea and after another two days pro-Russian militants rallyied in front of the new 
Parliament building of the newly created autonomous republic in Simferol to call for a national referendum and implicitly to reject central power in Kiev.

On February 24, 2014, several armed persons from the pro-Russian group occupied both the Parliament and Government headquarters in the Crimean Peninsula, where the Russian flags were flown. And on the night of February 27/28, 2014, many armed persons from the Russian-speaking group occupied the airports of the Crimean Peninsula.

In early March, Sergei Aksionov, the new prime minister of the peninsula, asked the Russian Federation, through the well-known president Vladimir Putin, to provide him with the necessary assistance to ensure peace and stability in the territory, in order to take over control over its security (Trenin, 2014). Also, the prime minister said that all authorities had the obligation to submit to all his orders, otherwise they have the option of resignation.

The first to react was that the US through President Barack Obama, who warned Russia of the implications, consequences and risks of a possible armed intervention in the Crimean Peninsula and in the eastern part of Ukraine. On the same day he received the request from the Prime Minister of the Crimean Peninsula, Russian leader Vladimir Putin in his turn requested permission from the Upper Chamber of the Russian Parliament to use armed forces in the Ukrainian territory, permission that was granted to him without any reservations.

Vladimir Putin motivated his request by invoking the so-called extraordinary situation that was in progress in the Ukrainian territory, a situation that would endanger the lives of the people of the Russian Federation. In addition, Putin also discussed the security of the troops he had already deployed on the borders of Ukraine and in Crimea, asking for permission to act in force to help normalize the political and social status of Crimea.

In parallel with the steps taken by Russian leader Vladimir Putin, the members of the Supreme Council of the newly founded Autonomous Republic of Crimea voted on March 6, 2014 to organize a national referendum to establish the status of the region, and also to officially exit the Ukrainian state structure and affiliate themselves to the Russian Federation.

Moreover, after five days, the Crimean Members of Parliament adopted a declaration of independence from Ukraine. In their turn, the Lower Chamber of the Parliament of the Russian Federation, the Duma, adopted a so-called declaration of support for the people of the peninsula, with the promise that it will consider ensuring the security of all the inhabitants of Crimea, regardless of ethnic origin, religion or language. The Russian leader Vladimir Putin could not refrain from comparing his country's intervention in the Crimean Peninsula with the action taken in Kosovo by the western states, stating however that armed intervention was not used in the Crimean situation.

\section{THE IMPACT OF THE OCCUPATION OF THE CRIMEAN PENINSULA}

Considering the national security context, but also the regional one, the problem of the Crimean Peninsula can have different valences, respectively political, military, economic, but also ethnic valences.

On a strictly political level, the conflict in Crimea is limited to an open confrontation between the numerous pro-Russian groups and the pro-Ukrainian category of the Ukrainian population. Supported by Russian armed forces, proRussian groups managed to establish their headquarters in Sevastopol, the main objective of pro-Ukrainian groups consisting in maintaining territorial integrity, 
absolute inviolability of state borders, as well as maintaining the status of the Republic of Crimea as an integral part Ukrainian territory.

As for the Ukrainian-Tatar alliance, it remains a rather fragile one, mainly because of the historical reminiscences, when deportation of the Tatars did not represent a priority for the Ukrainian nationalists, since they were not at all interested in the Tatars' wish for self-determination. In the current context, the situation of the Crimean Peninsula is proving to be quite complicated, especially considering the many economic problems that the Ukrainian stateis facing, but also the total lack of viable economic reforms withany chance of success.

Lately, there has been a continuous deterioration in the standard of living in the Crimean Peninsula, which has led to many dissatisfactions from the vast majority of the population, dissatisfaction directed mainly towards the government, but also towards the central administration. In addition, the proRussian secessionist movement has begun to attract more and more followers, especially because of the economic domination manifested by Moscow.

To these we can add the ethnicity of the population in the area, as well as the exploitation of its demographic situation by various political groups that have a direct and immediate interest in achieving personal goals. According to the 2001 census, in Crimea the vast majority of the population is composed of Russians (almost 60\%), while $77 \%$ of the total population of the peninsula declared their mother tongue Russian.

Russia, under the leadership of Vladimir Putin, continues to believe that it has a strategic right in relation to the Crimea region, especially in maintaining its presence within its bordes, which is why the armed forces available to it can be a real danger. In addition, Ukraine is facing an unprecedented economic decline in the absence of transitional reforms towards a real market economy, a decline characterized by the decrease in the volume of industrial production, but also a strong increase of inflation.

Under these conditions, Ukraine became included in the list of states that failed to successfully implement the various economic recovery programs after the collapse of the East-Soviet bloc, a failure not due to a lack of democracy, but mainly to the fact that its goverment is still based on the remanants of Soviet rules, which have a severel impact on economic recovery.

The special geopolitical crisis in Ukraine continues to be the focus of many international organizations and institutions, such as NATO, UNO, EU, USA, OSCE, but also of the Russian Federation. As far as to the policy of the western states towards Ukraine is regarded, a peaceful political settlement of the signalled disputes is provisioned, while maintaining good Russian-Ukrainian neighborhood relations, in parallel with the permanent control of the international bodies on the nuclear weapons within the territory of Ukraine (Morgenthau, 2007).

All procedures of the United Nations regarding the prevention and management of the Ukrainian political crisis, which are provided in the art. 34 of the ONU. Charter, have been carried out by taking no time in establishing operational relationships between the various bodies empowered to address political issues and the United Nations alert agencies. In this way, the ideal monitoring of the crisis was achieved, in parallel with the design and use of all the tools specially dedicated to crises of the kind reported in Ukraine (Sakwa, 2015).

Considering the legal instruments at its disposal, the UN can in due course take all the necessary measures in case of an escalation of the Ukrainian geopolitical crisis, as provided in the United Nations Charter. Moreover, according 
to article 40 of the Charter of the United Nations, it is explicitly stated that in order to prevent the worsening of a conflict situation, the Security Council may request all the parties involved to comply with any temporary measures that are considered necessary or desired.

In this regard, the General Assembly of the UNO passed a resolution recognizing the inviolability of Ukrainian territorial integrity, a resolution which was voted with 100 votes "for" and 11 votes "against", the negative votes being cast by states such as Russia, Belarus, Armenia, North Korea, Cuba, Bolivia, Syria, Sudan, Venezuela. It should also be noted that 58 states, including China, abstained from the vote.

Thus, it can be stated with certainty that the United Nations has a special role in managing within reasonable limits the geopolitical crisis that characterizes Ukraine, this being achieved not only through the use of decision-making and mandate procedures, but also through various devices of crisis prevention and the methods related to their management, devices and procedures elaborated at complex level, within the international security system.

In its turn, OSCE is directly interested in ensuring political and military stability in Ukraine, which translates by eliminating various motivations for potential armed conflicts, as well as by retaining various military structures in place for cases whenthe use of force might become necessary to resolve this geopolitical crisis.

In fact, many observers sent by this organization to the Ukrainian territory have encountered serious difficulties from the local security corps or have been even detained and arrested, being thus often prevented from doing their job. In addition, OSCE actively campaigned for the promotion of openness and total transparency in the official discussions between the Russian and Ukrainian authorities, the main purpose aimed in resolving this geopolitical crisis being the negotiation with all the important decision-makers in order to identify a peaceful resolution of the conflict.

Being an important security instrument based on cooperation, OSCE is constantly considering the provision of various mechanisms for agreement and negotiation that will allow Ukraine to go through this unprecedented situation both a geopolitical and a geostrategical point of view, thus trying to avoid the degeneration of the crisis in a full-blown regional conflict. The situation of Ukraine is also viewed with great interest by the leaders of the European Union, which has, among other things, the mandate to prevent conflicts and manage crises.

\section{CONCLUSION}

The events in Ukraine, which unfolded throughout the year 2014 and are still ongoing, as well as their global repercussions, had an impact on Russian geopolitical thinking. From the point of view of the Russian leadership, the Ukraine crisis demonstrated that Moscow cannot be part of the EAR in its current form. The sense of rejection and the failed attempts at integration were too heavy a burden. Russia's leaders consider their country to be one of the main powers in a multipolar international system and refuse to be pushed outside of this system. After a preliminary analysis of the implications of the Ukraine crisis, it can be concluded that Russia's geopolitical vision experienced a considerable shift. Before the Ukraine crisis, Russia considered itself to be a "full member" of the three geopolitical spaces Eurasia, Euro-Atlantic and Asia-Pacific. The Ukraine crisis brought to light that the traditional and decades-long rivalry with the US is still 
simmeringand the relationship between the US and Russia is in deadlock (Brzezinski, 2000). Russia's membership in the Euro-Atlantic space thus more and more resembled a farce.

Russia, in an analogous fashion to the German approach in the 1920-30s, is banking on the guilt complex of many Western capitals. There is, in fact, some ambivalence about NATO expansion, less so about EU enlargement, and if so, the remorse is more directed toward the southward extension of the Eurozone (Samarin, 2010). The ambivalence, or guilt complex, is twofold. First, the expansion of NATO to Central Europe is seen as having brought Europe closer to Russia, thus provoking Moscow that considered that region as its sphere of influence (Simion, 2009). It was an unnecessary "victory lap" after the miraculous 1989-1991 years. Second, now that the region is in, it may also be indefensible, in particular the Baltic states. In brief, the sentiment in some capitals of Europe is that NATO enlargement was a mistake and the best way to atone for it is by seeking a new settlement with Russia. So far, the new settlement negotiated with Russia includes Ukraine, until now only a potential member of the EU: Crimea is lost for now, and Eastern Ukraine is unlikely to be under control of Kiev anytime soon. The question is whether there will be a new order renegotiated with Russia that incorporates existing NATO and EU members.

\section{REFERENCES}

Ambrosio, T., \& Vandrovec, G. (2013). Mapping the geopolitics of the Russian federation: The federal assembly addresses of Putin and Medvedev. Geopolitics, 18(2), 435-466.

Brzezinski, Z. (2000). Marea Tablă de Şah, (The great chessboard), Editura Univers Enciclopedic, Bucureşti.

Buzan, B. (2000). Popoarele, statele şi teama (Peoples, States and Fear). Cartier, Chişinău.

Chifu, I. (2013). Gândire Strategică, (Strategic thinking), Editura Institutului de Ştiințe Politice și Relații Internaționale, Bucureşti.

Clover, C. (1999). Dreams of the Eurasian heartland: the re-emergence of geopolitics. Foreign Affairs, 78(2), 9-13.

Dughin, A. (2011). Bazele geopoliticii şi viitorul geopolitic al Rusiei, (The foundations of geopolitics and the geopolitical future of Russia), Editura Eurasiatica.ro, Bucureşti.

Dunlop, J. B. (1995). The rise of Russia and the fall of the Soviet empire. Princeton University Press.

Ingram, A. (2001). Alexander Dugin: geopolitics and neo-fascism in post-Soviet Russia. Political Geography, 20(8), 1029-1051.

King, C. (2004). The Black Sea: A History: A History. Oxford University Press, USA.

Maior, G. C., \& Konoplyov, S. (2011). Cunoaşterea strategică în zona extinsă a Mării Negre. Editura RAO, București.

Menon, R., \& Rumer, E. B. (2015). Conflict in Ukraine: The Unwinding of the Post-Cold War Order. Mit Press.

Morgenthau, H. (2007). Politica intre națiuni. Lupta pentru putere şi lupta pentru pace, (The politics between nations. The fight for power and the fight for peace), Editura Polirom, lassi.

O'Loughlin, J., Tuathail, G. Ó., \& Kolossov, V. (2006). The geopolitical orientations of ordinary Russians: A public opinion analysis. Eurasian Geography and Economics, 47(2), 129-152.

Sakwa, R. (2015). Frontline Ukraine: Crisis in the borderlands. London: I.B. Tauris.

Samarin, A. (2010). Moscow and Washington: Breaking Stereotypes, Nezavisimaia Gazeta, 29 January 2010.

Simion, O. (2009). Relația Rusia - NATO după destrămarea URSS: De la Războiul Rece la Parteneriatul pentru Pace, (Russia-NATO relationship after the break-up of the USSR: From the Cold War to the Partnership for Peace), Revista de Ştiințe Politice şi Relații Internaționale, (3).

Trenin, D. (2014). Russia's breakout from the Post-ColdWar system: The drivers of Putin's course. Moscow: Carnegie Endowment for International Peace.

Tsygankov, A. P. (2003). Mastering space in Eurasia: Russia's geopolitical thinking after the Soviet break-up. Communist and post-communist studies, 36(1), 101-127.

Vlad, L. B., Josan, A., \& Vlasceanu, G. (2010). Active geo-strategic players, geopolitical pivots and the changing balance of power in Eurasia. Revista Română de Geografie Politică (1), 116-125. 
Walker, E. W. (2015). Between east and west: NATO enlargement and the geopolitics of the Ukraine crisis. Ukraine and Russia: People, politics, propaganda and perspectives, 141-154.

http://ejes.uaic.ro/articles/EJES2014_0501_VLA.pdf, accessed May 20, 2019

http://www.afahc.ro/ro/revista/Nr_1_2012/Articol_Lazarescu.pdf, accessed May 20, 2019

http://www.clingendael.nl/sites/default/files/20060800_cdsp_occ_leitenberg.pdf, accessed May 15, 2019

http://www.epc.eu/documents/uploads/pub_1363_the_democratic_transformation_of_the_balkans. pdf, accessed May 15, 2019

http://www.epc.eu/documents/uploads/pub_1363_the_democratic_transformation_of_the_balkans. pdf, accessed May 18, 2019

http://www.un.org/esa/socdev/rwss/docs/2001/15\%20Armed\%20Conflict.pdf, accessed May 14, 2019

http://www.usislam.org/pdf/collapse-of-the-soviet-union.pdf, accessed May 15, 2019

https://fas.org/sgp/crs/natsec/R43838.pdf, accessed May 12, 2019

https://www.csis.org/analysis/nato-and-russia-black-sea-new-confrontation

www.nato.int

Submitted:

March 12, 2019
Revised:

December 04, 2019
Accepted and published online: February 17, 2020 